\title{
ANALYSIS OF CONVEYOR DRIVE POWER REQUIREMENTS IN THE MINING INDUSTRY
}

\author{
Greg Wheatley \\ College of Science \& Engineering, James Cook University, James Cook Dr, Douglas QLD 4814 Australia, \\ greg.wheatley@jcu.edu.au (corresponding author) \\ Robiul Islam Rubel \\ Department of Mechanical Engineering, Bangladesh Army University of Science and Technology, Saidpur 5310, \\ Bangladesh, rubel.ruet10@gmail.com
}

Keywords: mining, conveyor, drives, industrial logistics

Abstract: This article presents the analysis of conveyor drive power requirements for three typical mining conveyors. One of the conveyors was found not to be able to start when fully loaded. The analysis indicates that two of the conveyors are adequately powered while one is underpowered. This was found to be primarily the result of the maximum tonnage of the two adequately powered conveyors being 1500 tonnes per hour (TPH) while the inadequately powered conveyor was classed with a maximum tonnage of $1800 \mathrm{TPH}$. It is recommended that the current draw for each motor when fully loaded be measured. This will be compared to the design. Further analysis was done to allow $2000 \mathrm{TPH}$ on all conveyors. The required upgraded drive size is presented. This article does not address the structural adequacy of the supporting structure. Rather, only the capabilities of the conveyor belt and drives to transport the required TPH.

\section{Introduction}

The mining industry needs bulk material handling process for storage, transhipment, transfer, and transportation functions [1-4]. The bulk items may be ores, sand, gravel, stone, coal, cereals, wood etc. but not limited [5]. The traditional machinery and equipment of bulk material handling systems are truck dumpers, elevators, railcar dumpers, wagon tipplers, ship-loaders, hoppers, loaders classified as stationary and mobile type [6]. The conveyor drives can be used for bulk transporting for almost everything like extracted raw mineral, different mining equipment, worker's goods, and even the mineworkers [7-9]. Diverse conveyor drive and equipment can be found in service in both underground mines and surface mining [10].

The mining industry requires an enormous amount of energy for powering the conveyor drives [11-13]. In the mining industry, the emphasis is placed on improving the energy efficiency of conveyor drive power requirements. Power requirement analysis is essential for improving the conveyor drive energy efficiency in any mining industry [11]. The mining industry must pay enough attention to the conveyor drive power requirements analysis [3,12]. The viability of mining industry operations and future productivity largely depends on the optimization of conveyor drive power requirements. Thus, the associated conveyor drives of the mining industry should be kept tracked and study for conveyor drive energy efficiency. The study should also include the key parameter of the whole drive system to determine the actual power efficiency and suggestions that might help to upgrade the conveyor drive power requirements.
Vast works and research are available for energy optimization and modelling of conveyors drives. The optimization of energy has been done by the researchers for belt drive [9,11,14-15]. Among the available related research, Shirong Zhang et al. [9] worked on the energy efficiency optimization of the belt conveyors. K. P. Shah [14] worked on the belt conveyor for the construction of coal mine drive system, maintenance, and bulk material handling in coal plants that include the power consumption for the different ideal and industrial case. The driving force produced by a single conveyor drive in the mining industry might not satisfy the requirement for material handling in long transport as well as may not be suitable for high speed and heavy drive [11]. Thus, the number of the conveyor drive in the material handling of the mining industry differ based on the amount of bulk materials, hour of service, and operational types.

The logical solution for the above problem of the single drive conveyor is to use a multi conveyor drive $[7,11,16$ 17]. The total power available for conveyor drive can be distributed into the multi conveyor drive of the mining industry that can result in efficient mining production capacity and transport distances [7]. The multi conveyor drives have appeared as convenient for reducing drive system weights and achieving high performance [16]. To use the benefits of a multi conveyor drive, Mukalu Sandro Masaki et al. [16] has analysed and designed a costeffective belt conveyor drive system for bulk material handling. The study also compares the performance of the multi-drive conveyor with a single drive conveyor based on a previously developed drive system cost optimization model that is reported to have significant cost savings potential. 
The operational conditions of the conveyor drive vary on the application of the conveyor drive [4]. Conveyor drive system will be subjected to varying demand and operational conditions throughout its service in the mining industry [4]. The conveyor drive may be engaged for bulk transportation in the upward inclination or downward stepper direction $[1,11]$. Though the use of the conveyor drive is mainly to transport the extracted mining minerals but needs to meet the different conditions of operations that arise during mining [8]. The sudden operational conditions of the conveyor belt maybe change of motions, overloading, emergency stop and start etc. [18-20].

In some industrial use, multi conveyor drive can suffer from unequal power-sharing. A typical scenario faced by mine sites is that of when there is an emergency stop of a fully loaded conveyor. This is not ideal as restarting can be an issue along with overloading of the conveyor at the loading chute and subsequent spillage. Not being able to restart the conveyor can mean that manual unloading of the conveyor must take place which can take many hours resulting in significant downtime [21].

In the scenario presented in this article, a system of three conveyors was found to have issues with one conveyor not being able to restart when fully loaded. The analysis was done on the three conveyors by Belt Analyst supplied by Overland Conveyor. The required modification for the $15000 \mathrm{TPH}$ drive system has been proposed to upgrade it to $2000 \mathrm{TPH}$. Necessary key factors have been studied and re-assessed to drive the conveyor system that will eliminate the problem of sudden restarting with a new operating power $(\mathrm{kW})$ supply.

\section{Methodology}

Irrespective of the mining materials, the main operational activities in the solid mining industry are extraction, material transportation, and processing [12,9,22]. Among these, the main operating cost of mining largely depends on the material transportation that can reach up to $40 \%$ of the mining cost [23-24]. Mining involves bulk materials handling that is not easy to carry and shift by using conventional trucks due to power consumption and fuel price. For deep mining, material transportation becomes more challenging with conventional trucks [22,25]. Thus, mining experts generally rely on designing a transportation mechanism for materials transport at various processing stations of the mining site.

Since mining activities are merely associated with bulk materials handling, conveyor drive turns out to be a widely accepted solution for the miner of the world from the 1800's $[8,26]$. Initially, the idea of conveyor was for the coal mining industry but now being used for all kinds of the mining industry and in modern manufacturing lines such as in an automobile, agricultural, electronic, food, process, pharmaceutical, chemical, packaging industries [27-28]. It helps to reduce the handling cost drastically and has gain popularity. In the modern iron ore mining industry conveyor systems are an integral part of the transportation system [27-28].

The typical conveyor drive employed in the mining industry is a belt conveyor [2,7-9,23,29]. Belt conveyor is interpreted as a conventional conveyor system consist of two essential components. One is a belt that is allowed to move in a loop passage and the second is two pulleys fixed at either end of the loop. Pulleys are driven by an external power to circulate the belt over the pully roller in the loop continuously. The belt is loaded in one end and unloaded in the opposite end. The conveyor belt arrangement is installed depending on the length of the transportation required, site conditions and material handling rate etc. [2]. Many mining industries install a combination of different types of conveyor drive systems for convenient transportation of the extracted items.

In iron ore fines industries, belt conveyors drive to perform an essential function in nonstop material transport and logistics distributions. The operational cost of it significantly influences the cost of overall mining. All mining companies intend to design an effective drive system that will increase conveyor efficiency and provide reliable service with low maintenance costs [12]. Therefore, it needs an efficient, energy-saving conveyor drive mechanism for transportation in various branches of the industry [30-31]. The energy and drive optimization through the proper fittings of the belt conveyor system can also help and decreasing the number of conveyors [29].

As we know belt conveyor drive uses mechanical power given through pulleys and is mainly sourced by electrical motor drive [9], its energy efficiency can generally be improved by considering the drive's performance, operation, equipment, and technology [32]. S. Zhang et al. [9] used the methodology development to optimize and improve the operational efficiency of belt conveyors. The model proposed by S. Zhang et al. [9] consists of an analytic model collecting all the relevant parameters into four coefficients. The multi conveyor drive can have an effective benefit for optimized transportation in mining [33]. A lot of energy optimization model and case study-based solution is available from the previous research.

C.-H. Lan [33] designed a multi-drive system for the conveyor belt drive transportation system. Assuming a consecutive series of conveyor drives operating without interruption, the optimization considered the material handling, speed of the conveyor to improve the production profit. M. S. Masaki et al. [34] worked on the multi-drive belt conveyors technology to minimizing life cycle costs. The group considered a case study for an extensive simulation model to improve the economic benefit of the drive conveyors. The multiple conveyor drive system tends to affect unbalanced power distribution among the conveyor drives [21]. The uneven power distribution among the conveyor drive causes non-uniformity of material handling phenomenon $[18,20,35]$. Overall, either single or multi-drive mechanism, the analysis of the power 
requirement for the energy-efficient drive system is important. Besides this for any up-gradation of the drive system in any mining industry needs a reasonable choice of belt and idlers parameter.

R. Król et al. [36] worked on the determination of the actual efficiency of the power drive system through the analysis of the power requirement for a drive system. Then they compare the input power and actual power used to calculate the efficiency of the drive system. The methodology of power analysis employed for this work has been claimed to be applicable for belt conveyors drive systems which are frequently employed in the underground and surface mining. T. Mathaba et al. [37] worked on the optimization and energy-efficient function of the conveyor belt systems for a cement industry that uses downhill conveyors. A generic energy optimal scheduling model and economic analysis for belt conveyor deriving were anticipated for cost-effective conveyor belt systems.

S. Natalia [22] has discussed the belt conveyor equipment selection, conveying systems, operation, applied mining technology for different kinds of belt conveyors. The author took the concerns of idlers, belt, and drive system as a target of improving the belt conveyor drive efficiency. The conclusions said that the importance of the energy efficiency of belt conveyors and determining parametric relationship for analysis and assessment of energy efficiency of belt conveyors system consisting of 3 belt conveyors with the same volume of material but with different transportation inclination angle [22]. W. Kawalec et al. [29] did the same kind of belt conveyor analysis for technical and organizational improvements of the energyeffective drive system and ecologically friendly operation of the mining drive mechanism. J. Rodríguez et al. [38] worked on commissioning a new drive system for the transportation of ore in the mining industry. The drive system was designed following the requirements of a company. The specific drive systems included drive alternatives that may be utilized in the company and with a control strategy for the drive converters and conveyor belts.

A. Jennings et al. [20] did a case study on a long overland conveyor of Essroc Cement, part of the Italcementi Group, Nazareth plant in Pennsylvania. The complex multi-drive system was observed for control strategy. The starting and stopping strategies of the drive system were also discussed. W. Kung [39] presented a commissioning report of The Henderson Coarse Ore Conveying System. The commissioning deal with the startup, and operation of the conveyor belt, and mainly power efficiency of the conveyor was critically concentrated for improvement. When the motor drives the conveyor belt some slip occurs especially during starting, sudden load change, and load sharing among the drives [40]. Slip also affect the running characteristics of the belt conveyor. If sufficient power is not provided in the conveyor belt-drive, it may not be able to start.
For a multi conveyor belt drive, all the conveyor belts must be balanced to receive sufficient power for reliable operations. For unpredictable operational conditions like restarting at the fully loaded condition, the conveyor belt drive sometimes fails to restart. To resolve this fundamental operational problem of the belt drive, the functions of the conveyor's key components should be commissioned and upgrade regularly.

\section{Result and discussion}

During commissioning and regular maintenance of the mining industry, we found a multi-drive conveyor belt facing with restarting problem when fully loaded. For the intention of upgrading the conveyor system of that company, we executed a though analysis of the whole mechanism. Three conveyor belts were working in that company to transport iron ore fines. The conveyor profile drawings and datasheets for each conveyor were available. Each conveyor design tonnes per hour (TPH) capacity was known along with the properties of the material being transported, the horizontal and vertical pulley centre distances, the details of the carry and return idler sets, the belt details, the drive details, and the counterweight mass [41]. From these inputted details, the belt speed, belt capacity, DIN and drive power requirements were calculated. Both inputted and calculated values are presented in Table 1 below.

The conveyor belt "A", "B" and "C" was loaded with $1800 \mathrm{TPH}, 1500 \mathrm{TPH}, 1500 \mathrm{TPH}$ of iron ore fines. The centre distance for conveyors "A", "B", and "C" were 274 , 247 , and $89 \mathrm{~m}$ respectively with a vertical inclination of 18 , 11 , and $17 \mathrm{~m}$ between the start and endpoints. The long conveyor "A" had a conveying speed of $2.2 \mathrm{~m} / \mathrm{s}$ and "B" and " $C$ " had an equal speed of $1.8 \mathrm{~m} / \mathrm{s}$, slightly lower than the belt " $A$ ". The speed was calculated from the operations.

All three C6 CEMA type belts were at $35^{\circ}$ carry idler angle with side spacing of $1.2 \mathrm{~m}$. The return side spacing is $3 \mathrm{~m}$ for the same type of CEMA placed at $0^{\circ}$ return idler angle. The belt width for three conveyors is $900 \mathrm{~mm}$ with $10 \mathrm{~mm}$ top cover thickness, $4 \mathrm{~mm}$ bottom cover thickness and reported to have $81.9 \%, 82.1 \%$, and $82.1 \%$ belt capacity. The calculated demand power for the belt drives is $164 \mathrm{~kW}, 88 \mathrm{~kW}$, and $94 \mathrm{~kW}$. It indicates that the drive "A" is overpowered, and drive " $\mathrm{B}$ " and "C" are underpowered with respect to their designated power (Table 1).

As can be seen, although the belt capacity of all three conveyors is less than $100 \%$, the calculated demand power for conveyor " $\mathrm{A}$ " is more than the drive nameplate power. As such, when fully loaded, the conveyor would not be able to run, let alone start when there is a higher demand for power to enable all idlers to start rotating and to overcome any settling of the idler into the belt due to the weight of the product. It is recommended that the drive power amperage be measured on the conveyors to confirm that the analysis matches real-world measurements. 
ANALYSIS OF CONVEYOR DRIVE POWER REQUIREMENTS IN THE MINING INDUSTRY

Greg Wheatley; Robiul Islam Rubel

Table 1 Inputted and Calculated values for conveyors (current)

\begin{tabular}{|c|c|c|c|c|}
\hline Conveyor (current) & Inputted / Calculated & $\mathrm{A}$ & $\mathrm{B}$ & $\mathrm{C}$ \\
\hline TPH & Inputted & 1800 & 1500 & 1500 \\
\hline Material & Inputted & Iron ore fines & Iron ore fines & Iron ore fines \\
\hline Horizontal centre distance $(\mathrm{m})$ & Inputted & 274 & 247 & 89 \\
\hline Vertical centre distance $(\mathrm{m})$ & Inputted & 18 & 11 & 17 \\
\hline Belt speed $(\mathrm{m} / \mathrm{s})$ & Calculated & 2.2 & 1.8 & 1.8 \\
\hline Carry idler angle $\left(^{\circ}\right)$ & Inputted & 35 & 35 & 35 \\
\hline CEMA type & Inputted & $\mathrm{C} 6$ & $\mathrm{C} 6$ & C6 \\
\hline Carry side spacing $(\mathrm{m})$ & Inputted & 1.2 & 1.2 & 1.2 \\
\hline Return idler angle $\left({ }^{\circ}\right)$ & Inputted & 0 & 0 & 0 \\
\hline CEMA type & Inputted & $\mathrm{C} 6$ & $\mathrm{C} 6$ & $\mathrm{C} 6$ \\
\hline Return side spacing $(\mathrm{m})$ & Inputted & 3 & 3 & 3 \\
\hline Belt capacity $(\%)$ & Calculated & 81.9 & 82.1 & 82.1 \\
\hline Belt width $(\mathrm{mm})$ & Inputted & 900 & 900 & 900 \\
\hline Carcass & Inputted & PN1250/4 & PN1250/4 & PN1250/4 \\
\hline Cover compound & Inputted & AS-A & AS-A & AS-A \\
\hline Top cover thickness $(\mathrm{mm})$ & Inputted & 10 & 10 & 10 \\
\hline Bottom cover thickness $(\mathrm{mm})$ & Inputted & 4 & 4 & 4 \\
\hline DIN & Calculated & .0233 & .0212 & .0262 \\
\hline Counterweight $(\mathrm{kg})$ & Inputted & 7550 & 10000 & 6000 \\
\hline Drive nameplate power $(\mathrm{kW})$ & Inputted & 150 & 110 & 110 \\
\hline Calculated demand power $(\mathrm{kW})$ & Calculated & 164 & 88 & 94 \\
\hline
\end{tabular}

Table 2 Inputted and Calculated values for conveyors (upgraded)

\begin{tabular}{|c|c|c|c|c|}
\hline Conveyor (upgrade) & Inputted / Calculated & $\mathrm{A}$ & $\mathrm{B}$ & $\mathrm{C}$ \\
\hline TPH & Inputted & 2000 & 2000 & 2000 \\
\hline Material & Inputted & Iron ore fines & Iron ore fines & Iron ore fines \\
\hline Horizontal centre distance $(\mathrm{m})$ & Inputted & 274 & 247 & 89 \\
\hline Vertical centre distance $(\mathrm{m})$ & Inputted & 18 & 11 & 17 \\
\hline Belt speed $(\mathrm{m} / \mathrm{s})$ & Calculated & 2.6 & 2.6 & 2.7 \\
\hline Carry idler angle $\left(^{\circ}\right)$ & Inputted & 35 & 35 & 35 \\
\hline CEMA type & Inputted & $\mathrm{C} 6$ & $\mathrm{C} 6$ & C6 \\
\hline Carry side spacing $(\mathrm{m})$ & Inputted & 1.2 & 1.2 & 1.2 \\
\hline Return idler angle $\left(^{\circ}\right)$ & Inputted & 0 & 0 & 0 \\
\hline CEMA type & Inputted & C6 & C6 & C6 \\
\hline Return side spacing $(\mathrm{m})$ & Inputted & 3 & 3 & 3 \\
\hline Belt capacity $(\%)$ & Calculated & 77 & 77 & 74.2 \\
\hline Belt width $(\mathrm{mm})$ & Inputted & 900 & 900 & 900 \\
\hline Carcass & Inputted & PN1250/4 & PN1250/4 & PN1250/4 \\
\hline Cover compound & Inputted & AS-A & AS-A & AS-A \\
\hline Top cover thickness $(\mathrm{mm})$ & Inputted & 10 & 10 & 10 \\
\hline Bottom cover thickness $(\mathrm{mm})$ & Inputted & 4 & 4 & 4 \\
\hline DIN & Calculated & .0230 & .0211 & .0256 \\
\hline Counterweight $(\mathrm{kg})$ & Inputted & 7550 & 10000 & 6000 \\
\hline Drive nameplate power $(\mathrm{kW})$ & Inputted & 210 & 150 & 150 \\
\hline Calculated demand power $(\mathrm{kW})$ & Calculated & 184 & 120 & 127 \\
\hline
\end{tabular}

Balancing out all three conveyors on 2000 TPH was analysed in order to recommend what sort of drive upgrade would be required and to ensure that the existing belt would be able to cope with the potential increased capacity. All inputted data was identical except the desired upgraded TPH (Table 2). Drive power was increased in common commercially available increments until the drive power exceeded the calculated required drive power.

The analysis revealed that an increase on all three conveyors' drives was required in order to enable a throughput of $2000 \mathrm{TPH}$ through the system of three conveyors while still maintaining a belt capacity of less than $100 \%(77 \%, 77 \%$, and $74.2 \%)$. In the proposed 
upgraded design, the calculated belt speed for conveyor "A" become increased by $18.18 \%$, and for "B" and "C", the speed increased by $44.44 \%$ and $50 \%$ respectively. There was no change considered and suggested for the belt types and counterweighted. The DIN of the conveyor changes slightly and the proposed power for the drive system has $15 \sim 25 \%$ clearance to run upgraded $184 \mathrm{~kW}$, $120 \mathrm{~kW}$, and $127 \mathrm{~kW}$ drives.

The underlying structure must be analysed to determine if any changes there need to be made. As mentioned, the actual drive amperage should also be measured and compared to the analysis before any upgrade is carried out (Table 3).

Table 3 Summary of current and upgraded drive requirements

\begin{tabular}{|c|c|c|}
\hline Conveyor & Current $(\mathrm{kW})$ & Proposed $(\mathrm{kW})$ \\
\hline A & 150 & 210 \\
\hline B & 110 & 150 \\
\hline C & 110 & 150 \\
\hline
\end{tabular}

\section{Conclusions}

Material handling and transportation cause a substantial amount of costs in the mining industry. Regular commissioning, up-gradation, and power optimization become essential with such a phenomenon. This article presents the analysis of conveyor drive power requirements for three typical mining conveyors. One of the conveyors was found not to be able to start when fully loaded. The analysis indicates that two of the conveyors are adequately powered while one is underpowered. This was found to be primarily the result of the maximum tonnage of the two adequately powered conveyors being 1500 tonnes per hour (TPH) while the inadequately powered conveyor was classed with a maximum tonnage of $1800 \mathrm{TPH}$. It is recommended that the current draw for each motor when fully loaded be measured. This will be compared to the design. Further, the analysis was done to allow 2000 TPH on all conveyors. The required upgraded drive size is presented. This article does not address the structural adequacy of the supporting structure. Rather, only the capabilities of the conveyor belt and drives to transport the required $\mathrm{TPH}$.

\section{References}

[1] ROBERTS, W., SCOTT, O.J.: Bulk materials handling in the mining industry, Türkiye Xiii Madencilik Kongresi, pp. 9-20, 1993.

[2] BEBIC, M.Z., RISTIC, L.B.: Speed controlled belt conveyors: drives and mechanical considerations, Advances in Electrical and Computer Engineering, Vol. 18, No. 1, pp. 51-60, 2018. doi:10.4316/AECE.2018.01007

[3] ALSPAUGH, M.A.: Latest developments in belt conveyor technology, Presented on MINExpo 2004, Las Vegas, NV, USA. September 27, pp. 1-11, 2004.
[4] GEBLER, O.F., HICKS, B., YON, J., BARKER, M.: Characterising conveyor belt system usage from drive motor power consumption and rotational speed: $A$ feasibility study, Proceedings of the European Conference of the PHM Society 2018, Vol. 4, No. 1, pp. 1-16, 2018.

[5] INTEQNION B.V.: www.inteqnion.com: Bulk material handling, [Online], Available: https://www.inteqnion.com/en/industries/bulkmaterial-handling/ [02 Nov 2020] 2020.

[6] ALMASI, A.: Bulk material handling systems- all you need to know, [Online], Available: https://www.processingmagazine.com/materialhandling-dry-wet/article/15586935/bulk-materialhandling-systems-all-you-need-to-know, 2017 [02 Nov 2020], 2017.

[7] NUTTALL, A.: Design aspects of multiple driven belt conveyors, in TRAIL Thesis Series no. T2007/12, the Netherlands TRAIL, Research School, pp. 1-168, 2007.

[8] ETTEN, M.C. van: Application of conveyors in mining industry, Department Maritime and Transport Technology, Delft University of Technology, Transport Engineering and Logistics, Report number: 2016.TEL.8042, 2017.

[9] ZHANG, S., XIA, X.: Modeling and energy efficiency optimization of belt conveyors, Applied Energy, Vol. 88, No. 9, pp. 3061-3071, 2011. doi:10.1016/j.apenergy.2011.03.015

[10] National Research Council, Evolutionary and Revolutionary Technologies for Mining, Ch3 Technologies in exploration, mining, and processing, Washington, DC: The National Academies Press. 2002. doi:10.17226/10318

[11] YAO, Y., ZHANG, B.: Influence of the elastic modulus of a conveyor belt on the power allocation of multi-drive conveyors, PLoS One, Vol. 15, No. 7, pp. 1-16, 2020. doi:10.1371/journal.pone.0235768

[12] KROL, R., KAWALEC, W., GLADYSIEWICZ, L.: An effective belt conveyor for underground ore transportation systems, IOP Conf. Series: Earth and Environmental Science, Vol. 95, No. 4, pp. 1-9, 2017. doi:10.1088/1755-1315/95/4/042047

[13] BLAZEJ, R., JURDZIAK, L., KAWALEC, W.: Energy saving solutions for belt conveyors in lignite surface mines, Institute of Mining Engineering, Wroclaw University of Technology, 2013.

[14] SHAH, K.P.: Construction and maintenance of belt conveyors for coal and bulk material handling plants, www.practicalmaintenance.net, 2018.

[15] HOFMAN, T., STEINBUCH, M., DRUTEN, R.M. van: Modeling for simulation of hybrid drivetrain components, 2006 IEEE Vehicle Power and Propulsion Conference, Windsor, pp. 1-6. 2006. doi:10.1109/VPPC.2006.364269

[16] MASAKI, M.S., ZHANG, L., XIA, X.: A comparative study on the cost-effective belt conveyors for bulk material handling, Energy 
Procedia, Vol. 142, No. December, pp. 2754-2760, 2017. doi:10.1016/j.egypro.2017.12.221

[17] MASAKI, M.S., ZHANG, L., XIA, X.: Cost optimization design approach for multiple drive belt conveyors, $201736^{\text {th }}$ Chinese Control Conference (CCC), Dalian, pp. 2767-2772, 2017. doi:10.23919/ChiCC.2017.8027784

[18] FENG, Y., ZHANG, M., LI, G., MENG, G.: Dynamic characteristic analysis and startup optimization design of an intermediate drive belt conveyor with non-uniform load, Science Progress, Vol. 103, No. 1, pp. 1-20, 2020. doi:10.1177/0036850419881089

[19] GIRAUD, L., MASSÉ, S., DUBÉ, J., SCHREIBER, L., TURCOT, A.: A user's guide to conveyor belt safety, Copyright Deposit - Bibliothèque nationale du Québec, 2003.

[20] JENNINGS, A., PERRONE, P., CORNET, J.: Case study: correcting control problems on Essroc's multidrive station, horizontally curved conveyor, 2013 Transactions of the Society for Mining, Metallurgy, and Exploration, Vol. 334, pp. 472-476, 2013.

[21] DESPODOV, Z., MIJALKOVSKI, S., ADZISKI, V., PANOV, Z.: Selection of belt conveyors drive units number by technical - economical analysis, Applied Mechanics and Materials, Vol. 683, pp. 189-195, 2014.

doi:10.4028/www.scientific.net/AMM.683.189

[22] SUCHORAB, N.: Specific energy consumption - the comparison of belt conveyors, Mining Science, Vol. 26, pp. 263-274, 2019. doi:10.37190/msc192619

[23] ZHANG, S., XIA, X.: A new energy calculation model of belt conveyor, IEEE AFRICON, Kenya, Nairobi, pp. 1-6, 2009. doi:10.1109/AFRCON.2009.5308257

[24] ZHANG, S., XIA, X.: Optimal control of operation efficiency of belt conveyor systems, Applied Energy, Vol. 87, No. 6, pp. 1929-1937, 2010. doi:10.1016/j.apenergy.2010.01.006

[25] DARLING, P.: SME mining engineering handbook, $3^{\text {rd }}$ ed., Published by Society for Mining, Metallurgy, and Exploration, Inc. (SME), 2011.

[26] Queen's University, Conveyor systems, [Online], Available: https://minewiki.engineering.queensu.ca/ mediawiki/index.php/Conveyor_systems [02 Nov 2020], 2016.

[27] CHAVAN, P.B., BOBADE, A.M., MAHALE, D.S., BHADANE, V.R.: Review paper on low cost conveyor design reduction of weight of conveyor system, International Journal for Research in Applied Science \& Engineering Technology, Vol. 5, No. 3, pp. 1099-1104, 2017.

[28] RIBEIRO, B.G.C., SOUSA, W.T. de, LUZ, J.A.M. da: Feasibility project for implementation of conveyor belts in an iron ore mine. Study case: Fabrica Mine in Minas Gerais State, Brazil, Rem:
Revista Escola de Minas, Vol. 69, No. 1, pp. 79-83, 2016. doi:10.1590/0370-44672013690021

[29] KAWALEC, W., SUCHORAB, N., KONIECZNAFUŁAWKA, M., KRÓL, R.: Specific energy consumption of a belt conveyor system in a continuous surface mine, Energies, Vol. 13, No. 19, 2020. doi:10.3390/en13195214

[30] BAJDA, M., GEOLOGII, L.J.-W.G.G. I, BEŁCHATÓW, P.W.Z.K.-P.G.S.A.O. KWB: Comparison of electricity consumption by belt conveyors in a brown coal mine: Part 2. Study of the belt conveyors capacity influence, GÓRNICTWO Odkryw, Vol. 2019, No. 3, pp. 26-38, 2019.

[31] LODEWIJKS, G.: Energy saving options for continuous transport systems, an exploration, In F. Hassani, \& et al (Eds.), Proceedings $23^{\text {rd }}$ World Mining Congress, CIM, pp. 1-20, 2013.

[32] XIA, X., ZHANG, J.: Energy efficiency and control systems - from a POET perspective, IFAC Proceedings, Vol. 43, No. 1, pp. 255-260, 2010. doi:10.3182/20100329-3-PT-3006.00047

[33] LAN, C.H.: The design of a multi-conveyor system for profit maximisation, The International Journal of Advanced Manufacturing Technology, Vol. 22, No. July, pp. 510-521, 2003. doi:10.1007/s00170-0021512-y

[34] MASAKI, M.S., ZHANG, L., XIA, X.: A design approach for multiple drive belt conveyors minimizing life cycle costs, Journal of Cleaner Production, Vol. 201, No. November, pp. 526-541, 2018. doi:10.1016/j.jclepro.2018.08.040

[35] CHURCHILL, F.T.: Dynamic load sharing for conveyor belts with multiple drive stations, $12^{\text {th }} \mathrm{WVU}$ International Mining Electrotechnology Conference, West Virginia, USA, pp. 120-133, 1994. doi:10.1109/IMEC.1994.714124

[36] KRÓL, R., KASZUBA, D., KISIELEWSKI, W.: Determination of the mechanical power in belt conveyor's drive system in industrial conditions, IOP Conference Series: Earth and Environmental Science, Vol. 44, No. 042038, pp. 1-7, 2016. doi:10.1088/1755-1315/44/4/042038

[37] MATHABA, T., XIA, X.: Optimal and energy efficient operation of conveyor belt systems with downhill conveyors, Energy Efficiency, Vol. 10, No. July, pp. 405-417, 2017. doi:10.1007/s12053-0169461-8

[38] RODRÍGUEZ, J., PONTT, J., ALZAMORA, G., BECKER, N., EINENKEL, O., WEINSTEIN, A.: Novel $20 \mathrm{MW}$ downhill conveyor system using threelevel converters, IEEE Transactions on Industrial Electronics, Vol. 49, No. 5, pp. 1093-1100, 2002. doi:10.1109/TIE.2002.803223

[39] KUNG, W.: The Henderson coarse ore conveying system - a review of commissioning, start-up, and operation, Bulk material handling by belt conveyor 5 (Eds by A. Reicks, M.T. Myers), Published by 
Society for Mining, Metallurgy and Exploration, Inc., 2004.

[40] AULSON, G.E.: Statco Engineering Ltd.: Motor selection for belt conveyor drives, $10^{\text {th }}$ CIM Maintenance/Engineering Conference, Saskatoon, Saskatchewan, 1998.
[41] Belt conveyors for bulk materials, $5^{\text {th }}$ ed., Published by Conveyor Equipment Manufacturers Association. 1997.

\section{Review process}

Single-blind peer review process. 